\title{
Hypothesis Testing for the Questionnaire Investigation on Tourists' Behavior
}

\author{
Akane Okubo ${ }^{1}$, Yuki Higuchi ${ }^{2}$, Kazuhiro Takeyasu ${ }^{3}$ \\ ${ }^{1}$ NIHON University Junior College, Japan \\ ${ }^{2}$ Faculty of Business Administration, Setsunan, University \\ ${ }^{3}$ College of Business Administration, Tokoha University, Japan \\ Correspondence: Kazuhiro Takeyasu, College of Business Administration, Tokoha University, Shizuoka, \\ 417-0801 Japan.
}

Received: September 25, 2017

Accepted: October 11, $2017 \quad$ Online Published: October 27, 2017

doi:10.5539/ibr.v10n12p68

URL: https://doi.org/10.5539/ibr.v10n12p68

\begin{abstract}
Tourists from abroad are increasing rapidly in Japan. Kawazu town in Izu Peninsula is famous for its cherry trees. In the cherry blossom season, many tourists visit this town. The Kawazu Cherry Blossom Festival was carried out in February 2015. Our research investigation was performed during that period. In this paper, a questionnaire investigation is executed in order to clarify tourists' behavior, and to seek the possibility of developing regional collaboration among local government, tourism related industry and visitors. Hypothesis testing was executed based on that. We have set 10 Null hypotheses. In the hypothesis testing, 6 cases out of 10 null hypotheses were rejected and the majority of hypotheses were insisted clearly. We have obtained fruitful results.
\end{abstract}

Keywords: tourism, izu Peninsula, Kawazu Cherry Tree, hypothesis testing

\section{Introduction}

In recent years in Japan, the national and local governments have been trying to attract foreign tourists by using strategic approaches and developing tourist facilities, with the aim of promoting regional exchange and generating economic benefits. Particular aims of local government are to overcome the common problems of an aging population and declining birthrate through tourism-generated income and to stimulate the local society through regional exchange and migration. However, in order to take measures that will increase tourism, it is necessary to understand the attraction of particular regions in Japan, as well as the resources they offer to tourists. Moreover, it is necessary to have a picture of the tourists that might want to visit such regions.

Although it is useful to have an understanding of an issue at a given time and under specific social conditions, it is difficult to analyze chronological changes or cross-regional trends statistically. It is standard practice to design a survey such that it permits examination of the statistics for a given region over time, but in order to investigate solutions to problems shared across regions it is necessary to carefully examine the critical basic data as well as appropriate methods of data collection.

To try to obtain such data, preceding studies on tourist destinations that have statistically analyzed trends in tourist behavior will now be reviewed. Yoshida et al. designed and conducted a visitor survey on the spot, which used a questionnaire to investigate the activities of visitors to the Ueno district in Taito ward, Tokyo. Doi et al. analyzed the image of the Izu Peninsula as a tourist destination in their 2003 study "Questionnaire Survey on the Izu Peninsula." Kano conducted tourist behavior studies in Atami city in 2008, 2009, 2014 and in other years.

Kawazu town in Izu Peninsula is famous for its cherry trees. In the cherry blossom season, many tourists visit this town. In this paper, a questionnaire investigation was executed in Kawazu town in February 2015, which was conducted to coincide with events on the Izu Peninsula featuring flowers; the Kawazu Sakura Festival (Feb-Mar), and ways that regions can collaborate to carry out surveys of tourist behavior was also performed.

This survey of tourist behavior was carried out in February 2015, during the Kawazu Cherry Blossom Festival. Given the geographical peculiarities of Kawazu town and its relative lack of accommodation facilities, some of the survey personnel were located also at Izukyu-Inatori Station and Izukyu-Shimoda Station. On the first day of the survey, the weather was good, while on the second it was raining. The 25th Kawazu Cherry Blossom Festival 
was held from February 10 to March 10, 2015. It was attended by 801,330 people, which was an increase of $9 \%$ over the previous year. On the first day of the survey, 30-50\% of the flowers were in bloom, and the nighttime illuminations lit up on the evening of the 21st. According to the figures of the Kawazu town Tourist Association, there were 30,590 visitors on the 21 st and 20,913 visitors on the 22nd. During the Kawazu Cherry Blossom Festival, around 150 stores were offering food \& drink or souvenirs on the road with the row of cherry trees linked to Kawazu Station. A number of events were held during the festival, including the "Semi Gourmet" and "Izu no Odoriko Photography Event."

In this paper, a questionnaire investigation is executed in order to clarify tourists' behavior, and to seek the possibility of developing regional collaboration among local government, tourism related industry and visitors. Hypothesis testing was executed based on that. We have made 10 Null hypotheses based upon these and hypothesis testing is executed. Some interesting results were obtained.

The rest of the paper is organized as follows. Outline of questionnaire investigation is stated in section 2 . Hypothesis Testing is carried out in section 3, which is followed by the Remarks of section 4 .

\section{Outline and Basic Statistical Results of the Questionnaire Research}

\subsection{Outline of the Questionnaire Research}

We make a questionnaire investigation on tourists' behavior who has visited Izu Peninsula and is studied mainly at Kawazu town in Shizuoka Prefecture. Kawazu town is famous for its cherry trees. The outline of questionnaire research is as follows. Questionnaire sheet is attached in Appendix.
(1) Scope of investigation
Tourists who have visited Kawazu town in Shizuoka Prefecture, Japan
(2) Period
February 21,22/ 2015
(3) Method
Local site, Dispatch sheet, Self writing
(4) Collection
: Number of distribution 500
Number of collection 478 (collection rate $95.6 \%$ )
Valid answer 478

\subsection{Basic Statistical Results}

Now, we show the main summary results by single variable.

\section{(1) Basic characteristics of answerers}

Q1 Address

\begin{tabular}{lrr}
\hline & Frequency & $\%$ \\
\hline vicinity & 163 & 64.7 \\
distance & 89 & 35.3 \\
\hline Total & 252 & 100.0 \\
\hline
\end{tabular}

\section{Q3 Age}

\begin{tabular}{lrr}
\hline & Frequency & $\%$ \\
\hline $10-19$ & 6 & 2.9 \\
$20-29$ & 35 & 17.1 \\
$30-39$ & 33 & 16.1 \\
$40-49$ & 32 & 15.6 \\
$50-59$ & 38 & 18.5 \\
$60-69$ & 44 & 21.5 \\
$70-$ & 17 & 8.3 \\
\hline Total & 205 & 100.0 \\
\hline
\end{tabular}

Q2 Sex

\begin{tabular}{lrr}
\hline & Frequency & $\%$ \\
\hline Male & 99 & 40.2 \\
Female & 147 & 59.8 \\
\hline Total & 246 & 100.0 \\
\hline
\end{tabular}

Q4 Occupation

\begin{tabular}{lrr}
\hline & Frequency & $\%$ \\
\hline Independents & 9 & 4.2 \\
Office worker & 118 & 55.1 \\
Student & 10 & 4.7 \\
Housewife & 35 & 16.4 \\
No job & 34 & 15.9 \\
Miscellaneous & 8 & 3.7 \\
\hline Total & 214 & 100.0 \\
\hline
\end{tabular}


Q5 Fellow travelers

\begin{tabular}{lrr}
\hline & Frequency & $\%$ \\
\hline Solo trip & 6 & 2.4 \\
Couple & 85 & 33.7 \\
Family & 89 & 35.3 \\
Male's small group & 10 & 4.0 \\
Female's small group & 25 & 9.9 \\
Male and female's small group & 21 & 8.3 \\
Group (More than 7) & 14 & 5.6 \\
Miscellaneous & 2 & 0.8 \\
\hline Total & 252 & 100.0 \\
\hline
\end{tabular}

\section{(2) Summary resul ts for the items used in Hypothesis Testing}

Q6A Visiting frequency to Izu Peninsula and

Kaw azu Cherry Tree : Izu Peninsula

\begin{tabular}{lrr}
\hline & Frequency & $\%$ \\
\hline First time & 37 & 14.6 \\
Second times & 23 & 9.1 \\
Third times & 24 & 9.5 \\
Fourth times & 14 & 5.5 \\
Fifth-Nine times & 53 & 20.9 \\
More than ten times & 102 & 40.3 \\
\hline Total & 253 & 100.0 \\
\hline
\end{tabular}

Q6B Visiting frequency to Izu Peninsula and

Kaw azu Cherry Tree : Kaw azu Cherry Tree

\begin{tabular}{lrr}
\hline & Frequency & $\%$ \\
\hline First time & 118 & 49.0 \\
Second times & 38 & 15.8 \\
Third times & 32 & 13.3 \\
Fourth times & 17 & 7.1 \\
Fifth-Nine times & 19 & 7.9 \\
More than ten times & 17 & 7.1 \\
\hline Total & 241 & 100.0 \\
\hline
\end{tabular}

Q7 Means of transportation to Izu Peninsula

\begin{tabular}{lrr}
\hline & Frequency & $\%$ \\
\hline JR, Izu-kyuko train & 151 & 60.6 \\
Sightseeing bus & 19 & 7.6 \\
Private automobile & 71 & 28.5 \\
Miscellaneous & 8 & 3.2 \\
\hline Total & 249 & 100.0 \\
\hline
\end{tabular}

Q9 Main occasion to visit to Izu Peninsula : (1)Poster

\begin{tabular}{lrr}
\hline & Frequency & $\%$ \\
\hline Yes & 26 & 10.5 \\
No & 221 & 89.5 \\
\hline Total & 247 & 100.0 \\
\hline
\end{tabular}

Q9 Main occasion to visit to Izu Peninsula :

(10)Felt good at the previous visit

\begin{tabular}{lrr}
\hline & Frequency & $\%$ \\
\hline Yes & 62 & 25.1 \\
No & 185 & 74.9 \\
\hline Total & 185 & 100.0 \\
\hline
\end{tabular}

Q10 What is an objective to visit Izu Peninsula? : (1)Hot spring

\begin{tabular}{lrr}
\hline & Frequency & $\%$ \\
\hline Yes & 109 & 44.1 \\
No & 138 & 55.9 \\
\hline Total & 247 & 100.0 \\
\hline
\end{tabular}

Q10 What is an objective to visit Izu Peninsula? : (3)Dish, sense of taste

\begin{tabular}{lrr}
\hline & Frequency & $\%$ \\
\hline Yes & 75 & 30.4 \\
No & 172 & 69.6 \\
\hline Total & 247 & 100.0 \\
\hline
\end{tabular}

Q10 What is an objective to visit Izu Peninsula? : (5) Stroll around town, Eating tour

\begin{tabular}{lrr}
\hline & Frequency & $\%$ \\
\hline Yes & 19 & 7.7 \\
No & 228 & 92.3 \\
\hline Total & 247 & 100.0 \\
\hline
\end{tabular}

Q10 What is an objective to visit Izu Peninsula? : (7) Convenience of traffic

\begin{tabular}{lrr}
\hline & Frequency & $\%$ \\
\hline Yes & 14 & 5.7 \\
No & 233 & 94.3 \\
\hline Total & 247 & 100.0 \\
\hline
\end{tabular}

Q11 Staying time in Izu Peninsula

\begin{tabular}{lrr}
\hline & Frequency & $\%$ \\
\hline One-day trip & 49 & 19.3 \\
2 days stay & 167 & 65.7 \\
3 days stay & 35 & 13.8 \\
More than 4 days & 3 & 1.2 \\
\hline Total & 254 & 100.0 \\
\hline
\end{tabular}

Q14-1 Select items in each theme concerning the attractiveness of southern part of Izu Peninsula. : Sea bathing

\begin{tabular}{lrr}
\hline & Frequency & $\%$ \\
\hline Yes & 61 & 32.4 \\
No & 127 & 67.6 \\
\hline Total & 188 & 100.0 \\
\hline
\end{tabular}


Q16(3) How about the expenditure or budget of the following items in Izu Peninsula? : Souvenir, Shopping

\begin{tabular}{lrr}
\hline & Frequency & $\%$ \\
\hline$\sim 1,000$ & 25 & 11.8 \\
$1,001 \sim 2,000$ & 34 & 16.1 \\
$2,001 \sim 3,000$ & 47 & 22.3 \\
$3,001 \sim 5,000$ & 46 & 21.8 \\
$5,001 \sim$ & 59 & 28.0 \\
\hline Total & 211 & 100.0 \\
\hline
\end{tabular}

\section{Hypothesis Testing}

Hereinafter we make hypothesis testing based upon the questionnaire investigation data.

\subsection{Setting Hypothesis}

We set the following 10 themes before setting Null Hypothesis.

A-1) Those who are young have the image of Izu Peninsula as "sea bathing".

A-2) Those who live far away (Chugoku, Remote part of Kanto area) often use sightseeing bus.

A-3) Those who live far away have many souvenir budget (more than 5000 Japanese Yen).

A-4) Those who are couple often visit Izu Peninsula (more than 5 times).

A-5) Those who live nearby (Shizuoka, Kanagawa, Tokyo) often visit Izu Peninsula by private automobile.

A-6) Those who felt good at the previous visit to Izu Peninsula consists mainly by repeaters.

A-7) Those who felt good at the previous visit to Kawazu Town consists mainly by repeaters.

A-8) Those who visit for the purpose of hot spring often come for more than 2 days.

A-9) Those who visit Izu Peninsula by one-day trip consist mainly by the people who live nearby (Shizuoka, Kanagawa, Tokyo).

A-10) Those who visit Izu Peninsula by the occasion of "Poster" often use JR or Izu-Kyuko train.

Now, we set the following 10 Null hypotheses.

B-1) There is not so much difference whether "those who are young have the image of Izu Peninsula as "sea bathing"' or not.

B-2) There is not so much difference whether "those who live far away (Chugoku, Remote part of Kanto area) often use sightseeing bus" or not.

B-3) There is not so much difference whether "those who live far away have many souvenir budget (more than 5000 Japanese Yen)" or not.

B-4) There is not so much difference whether "those who are couple often visit Izu Peninsula (more than 5 times)" or not.

B-5) There is not so much difference whether "those who live nearby (Shizuoka, Kanagawa, Tokyo) often visit Izu Peninsula by private automobile" or not.

B-6) There is not so much difference whether "those who felt good at the previous visit to Izu Peninsula consists mainly by repeaters" or not.

B-7) There is not so much difference whether "those who felt good at the previous visit to Kawazu Town consists mainly by repeaters" or not.

B-8) There is not so much difference whether "those who visit for the purpose of hot spring often come for more than 2 days" or not.

B-9) There is not so much difference whether "those who visit Izu Peninsula by one-day trip consist mainly by the people who live nearby (Shizuoka, Kanagawa, Tokyo)" or not.

B-10) There is not so much difference whether "those who visit Izu Peninsula by the occasion of "Poster" often use JR or Izu-Kyuko train" or not. 


\subsection{Hypothesis Testing}

$x^{2}$ hypothesis testing is executed in order to clarify tourists' behavior. $x^{2}$ hypothesis testing is to clarify the difference between the expected value and the observed data, which is shown in Eq.(1).

$$
x^{2}=\sum_{i=1}^{n} \frac{\left(O_{i}-E_{i}\right)^{2}}{E_{i}}
$$

Where $O_{i}$ is an observed data and $E_{i}$ is an expected value. The results of statistical hypothesis testing are as follows.

Null Hypothesis B-1) There is not so much difference whether "those who are young have the image of Izu Peninsula as "sea bathing"" or not.

Summary table concerning Null Hypothesis B-1) is exhibited in Table 1.

Table 1. Summary table for Null Hypothesis B-1)

\begin{tabular}{|c|c|c|c|c|}
\hline \multirow[t]{2}{*}{ Q3 Age } & \multicolumn{4}{|c|}{$\begin{array}{l}\text { Q14-1 Select items in each theme concerning the } \\
\text { attractiveness of southern part of Izu Peninsula. }\end{array}$} \\
\hline & & Yes & No & Total \\
\hline \multirow{2}{*}{ Under 39} & Frequency & 26 & 34 & 60 \\
\hline & $\%$ & 43.3 & 56.7 & 100.0 \\
\hline \multirow{2}{*}{ Over 40} & Frequency & 28 & 72 & 100 \\
\hline & $\%$ & 28.0 & 72.0 & 100.0 \\
\hline \multirow{2}{*}{ Total } & Frequency & 54 & 106 & 160 \\
\hline & $\%$ & 33.8 & 66.3 & 100.0 \\
\hline
\end{tabular}

The null hypothesis is rejected with 5\% significance level. It can be said that those who are young have the image of Izu Peninsula as "sea bathing". (Rejection region is over 6.6349 for 1\% significance level, 3.841 for 5\% significance level, 3.537 for $6 \%$ significance level and 2.874 for $9 \%$ significance level by 1 degree of freedom.)

Null Hypothesis B-2): There is not so much difference whether "those who live far away (Chugoku, Remote part of Kanto area) often use sightseeing bus" or not.

Summary table concerning Null Hypothesis B-2) is exhibited in Table 2.

Table 2. Summary table for Null Hypothesis B-2)

\begin{tabular}{|c|c|c|c|c|}
\hline \multirow[t]{2}{*}{ Q1 Address } & \multicolumn{4}{|c|}{$\begin{array}{l}\text { Q7 Means of transportation to } \\
\text { IZU Peninsula : Sightseeing bus }\end{array}$} \\
\hline & & Yes & No & Total \\
\hline \multirow{2}{*}{ vicinity } & Frequency & 14 & 144 & 158 \\
\hline & $\%$ & 8.9 & 91.1 & 100.0 \\
\hline \multirow{2}{*}{ distance } & Frequency & 5 & 84 & 89 \\
\hline & $\%$ & 5.6 & 94.4 & 100.0 \\
\hline \multirow{2}{*}{ Total } & Frequency & 19 & 228 & 247 \\
\hline & $\%$ & 7.7 & 92.3 & 100.0 \\
\hline
\end{tabular}

The null hypothesis is not rejected. It can be said that there is not so much difference whether "those who live far away (Chugoku, Remote part of Kanto area) often use sightseeing bus" or not.

Null Hypothesis B-3): There is not so much difference whether "those who live far away have many souvenir budget (more than 5000 Japanese Yen)" or not.

Summary table concerning Null Hypothesis B-3) is exhibited in Table 3. 
Table 3. Summary table for Null Hypothesis B-3)

Q16(3) How about the expenditure or budget of the

\begin{tabular}{cccrr} 
Q1 Address & & $\begin{array}{c}\text { following items in Izu Peninsula? : Souvenir, Shopping } \\
\text { Under 5000 yen }\end{array}$ & Over 5001 yen & \multicolumn{2}{c}{ Total } \\
\hline \multirow{2}{*}{ vicinity } & Frequency & 105 & 31 & 136 \\
& $\%$ & 77.2 & 22.8 & 100.0 \\
\hline \multirow{2}{*}{ distance } & Frequency & 45 & 28 & 73 \\
& $\%$ & 61.6 & 38.4 & 100.0 \\
\hline \multirow{2}{*}{ Total } & Frequency & 150 & 59 & 209 \\
& $\%$ & 71.8 & 28.2 & 100.0 \\
\hline & & & significance probability & 0.017
\end{tabular}

The null hypothesis is rejected with $2 \%$ significance level. It can be said that those who live far away have many souvenir budget (more than 5000 Japanese Yen).

Null Hypothesis B-4): There is not so much difference whether "those who are couple often visit Izu Peninsula (more than 5 times)" or not.

Summary table concerning Null Hypothesis B-4) is exhibited in Table 4.

Table 4. Summary table for Null Hypothesis B-4)

\begin{tabular}{|c|c|c|c|c|}
\hline \multicolumn{2}{|c|}{ Q5 Fellow travelers } & \multicolumn{2}{|c|}{$\begin{array}{l}\text { Q6A Visiting frequency to Izu Peninsula } \\
\text { and Kawazu Cherry Tree : Izu Peninsula }\end{array}$} & \multirow[b]{2}{*}{ Total } \\
\hline & & Under 4 times & Over 5 times & \\
\hline \multirow{2}{*}{ Couple } & Frequency & 31 & 57 & 88 \\
\hline & $\%$ & 35.2 & 64.8 & 100.0 \\
\hline \multirow{2}{*}{ Others } & Frequency & 67 & 96 & 163 \\
\hline & $\%$ & 41.1 & 58.9 & 100.0 \\
\hline \multirow{2}{*}{ Total } & Frequency & 98 & 153 & 251 \\
\hline & $\%$ & 39.0 & 61.0 & 100.0 \\
\hline
\end{tabular}

The null hypothesis is not rejected. It can be said that there is not so much difference whether "those who are couple often visit Izu Peninsula (more than 5 times)" or not.

Null Hypothesis B-5): There is not so much difference whether "those who live nearby (Shizuoka, Kanagawa, Tokyo) often visit Izu Peninsula by private automobile" or not.

Summary table concerning Null Hypothesis B-5) is exhibited in Table 5.

Table 5. Summary table for Null Hypothesis B-5)

\begin{tabular}{|c|c|c|c|c|}
\hline \multirow[t]{2}{*}{ Q1 Address } & \multicolumn{4}{|c|}{$\begin{array}{l}\text { Q7 Means of transportation to IZU } \\
\text { Peninsula : (3)Private automobile }\end{array}$} \\
\hline & & Yes & No & Total \\
\hline \multirow{2}{*}{ vicinity } & Frequency & 48 & 110 & 158 \\
\hline & $\%$ & 30.4 & 69.6 & 100.0 \\
\hline \multirow{2}{*}{ distance } & Frequency & 23 & 66 & 89 \\
\hline & $\%$ & 25.8 & 74.2 & 100.0 \\
\hline \multirow{2}{*}{ Total } & Frequency & 71 & 176 & 247 \\
\hline & $\%$ & 28.7 & 71.3 & 100.0 \\
\hline
\end{tabular}

The null hypothesis is not rejected. It can be said that there is not so much difference whether "those who live nearby (Shizuoka, Kanagawa, Tokyo) often visit Izu Peninsula by private automobile" or not.

Null Hypothesis B-6): There is not so much difference whether "those who felt good at the previous visit to Izu Peninsula consists mainly by repeaters" or not. 
Summary table concerning Null Hypothesis B-6) is exhibited in Table 6.

Table 6. Summary table for Null Hypothesis B-6)

\begin{tabular}{|c|c|c|c|c|}
\hline \multirow{2}{*}{$\begin{array}{l}\text { Q9 Main occasion to visit } \\
\text { to Izu Peninsula : } \\
\text { Felt good at the previous visit }\end{array}$} & & \multicolumn{3}{|c|}{$\begin{array}{l}\text { Q6A Visiting frequency to Izu Peninsula } \\
\text { and Kawazu Cherry Tree : Izu Peninsula }\end{array}$} \\
\hline & & Under 4 times & Over 5 times & Total \\
\hline & Frequency & 11 & 51 & $\overline{62}$ \\
\hline Yes & $\%$ & 17.7 & 82.3 & 100.0 \\
\hline No & Frequency & 87 & 97 & $\overline{184}$ \\
\hline No & $\%$ & 47.3 & 52.7 & 100.0 \\
\hline Toto & Frequency & 98 & 148 & 246 \\
\hline 1 otal & $\%$ & 39.8 & 60.2 & 100.0 \\
\hline
\end{tabular}

The null hypothesis is rejected with $1 \%$ significance level. It can be said that those who felt good at the previous visit to Kawazu Town consists mainly by repeaters.

Null Hypothesis B-7): There is not so much difference whether "those who felt good at the previous visit to Kawazu Town consists mainly by repeaters" or not.

Summary table concerning Null Hypothesis B-7) is exhibited in Table 7.

Table 7. Summary table for Null Hypothesis B-7)

\begin{tabular}{ccrrr}
\hline $\begin{array}{c}\text { Q9 Main occasion to visit } \\
\text { to Izu Peninsula : } \\
\text { Felt good at the previous visit }\end{array}$ & & \multicolumn{2}{c}{$\begin{array}{c}\text { Q6B Visiting frequency to Izu Peninsula and } \\
\text { Kaw azu Cherry Tree : Kaw azu Cherry Tree } \\
\text { Under 4 times }\end{array}$} & $\begin{array}{c}\text { Over 5 times } \\
\text { Total }\end{array}$ \\
\hline \multirow{2}{*}{ Yes } & Frequency & 42 & 17 & 59 \\
& $\%$ & 71.2 & 28.8 & 100.0 \\
\hline \multirow{2}{*}{ No } & Frequency & 163 & 16 & 179 \\
& $\%$ & 91.1 & 8.9 & 100.0 \\
\hline \multirow{2}{*}{ Total } & Frequency & 205 & 33 & 238 \\
& $\%$ & 86.1 & 13.9 & 100.0 \\
\hline
\end{tabular}

The null hypothesis is rejected with $1 \%$ significance level. It can be said that those who felt good at the previous visit to Kawazu Town consists mainly by repeaters.

Null Hypothesis B-8): There is not so much difference whether "those who visit for the purpose of hot spring often come for more than 2 days" or not.

Summary table concerning Null Hypothesis B-8) is exhibited in Table 8.

Table 8. Summary table for Null Hypothesis B-8)

\begin{tabular}{|c|c|c|c|c|}
\hline \multirow{2}{*}{$\begin{array}{l}\text { Q10 What is an objective to visit } \\
\text { Izu Peninsula? : (1)Hot spring }\end{array}$} & \multicolumn{4}{|c|}{ Q11 Staying time in Izu Peninsula } \\
\hline & & One-day trip & Over 2 days stay & Total \\
\hline \multirow{2}{*}{ Yes } & Frequency & 6 & 103 & 109 \\
\hline & $\%$ & 5.5 & 94.5 & 100.0 \\
\hline \multirow{2}{*}{ No } & Frequency & 42 & 96 & 138 \\
\hline & $\%$ & 30.4 & 69.6 & 100.0 \\
\hline \multirow{2}{*}{ Total } & Frequency & 48 & 199 & 247 \\
\hline & $\%$ & 19.4 & 80.6 & 100.0 \\
\hline
\end{tabular}

The null hypothesis is rejected with $1 \%$ significance level. It can be said that those who visit for the purpose of hot spring often come for more than 2 days.

Null Hypothesis B-9): There is not so much difference whether "those who visit Izu Peninsula by one-day trip 
consist mainly by the people who live nearby (Shizuoka, Kanagawa, Tokyo)" or not.

Summary table concerning Null Hypothesis B-9) is exhibited in Table 9.

Table 9. Summary table for Null Hypothesis B-9)

\begin{tabular}{ccrrr}
\hline \multirow{2}{*}{ Q1 Address } & \multicolumn{4}{c}{ Q11 Staying time in Izu Peninsula } \\
& & One-day trip & Over 2 days stay & \multicolumn{1}{c}{ Total } \\
\hline \multirow{2}{*}{ vicinity } & Frequency & 42 & 121 & 163 \\
& $\%$ & 25.8 & 74.2 & 100.0 \\
\hline \multirow{2}{*}{ distance } & Frequency & 7 & 82 & 89 \\
& $\%$ & 7.9 & 92.1 & 100.0 \\
& Frequency & 49 & 203 & 252 \\
\multirow{2}{*}{ Total } & $\%$ & 19.4 & 80.6 & 100.0 \\
& & & signific ance probability & 0.001
\end{tabular}

The null hypothesis is rejected with $1 \%$ significance level. It can be said that those who visit Izu Peninsula by one-day trip consist mainly by the people who live nearby (Shizuoka, Kanagawa, Tokyo).

Null Hypothesis B-10): There is not so much difference whether "those who visit Izu Peninsula by the occasion of "Poster" often use JR or Izu-Kyuko train" or not.

Summary table concerning Null Hypothesis B-10) is exhibited in Table 10.

Table 10. Summary table for Null Hypothesis B-10)

\begin{tabular}{|c|c|c|c|c|}
\hline \multirow{2}{*}{$\begin{array}{l}\text { Q1 Main occasion to visit } \\
\text { to Izu Peninsula : (1) } \\
\text { Poster }\end{array}$} & & \multicolumn{2}{|c|}{$\begin{array}{l}\text { Q7 Means of transportation to IZU } \\
\text { Peninsula : (2) Sightseeing bus }\end{array}$} & \multirow[b]{2}{*}{ Total } \\
\hline & & Public transport & Others & \\
\hline \multirow{2}{*}{ Yes } & Frequency & 19 & 7 & 26 \\
\hline & $\%$ & 73.1 & 26.9 & 100.0 \\
\hline \multirow{2}{*}{ No } & Frequency & 145 & 72 & 217 \\
\hline & $\%$ & 66.8 & 33.2 & 100.0 \\
\hline \multirow{2}{*}{ Total } & Frequency & 164 & 79 & 243 \\
\hline & $\%$ & 67.5 & 32.5 & 100.0 \\
\hline
\end{tabular}

The null hypothesis is not rejected. It can be said that there is not so much difference whether "those who visit Izu Peninsula by the occasion of "Poster" often use JR or Izu-Kyuko train" or not.

\section{Remarks}

The main results of basic statistical analysis are as follows.

(1) The visitors were of all ages, from 20s to 70s-or-over, with no particular tendency towards visitors of a certain age group.

(2) As regards the type of trip, most visitors had come as individuals, and a mere $8 \%$ had come as part of a group. Looking at specific age groups, although married and unmarried couples were common across all age groups, those aged 10-19 and those in their 40s tended to be visiting with their families.

(3) The majority of visitors had been five or more times to the Izu Peninsula, indicating a tendency towards multiple repeat visits.

(4) Most visitors to the Kawazu Cherry Blossom Festival were attending the event for the first or second time. It may be that advertising promotion or the like had caused visitors to come to the festival.

(5) Most visitors came to the Izu Peninsula by train, and the majority of visitors moved around the Izu Peninsula solely on foot, or by train or bus. Only $3.14 \%$ of the visitors traveled to the west coast of the peninsula. This may be because the available transport in the area tends to serve the east coast.

(6) For around half of the visitors, what prompted them to come to Izu was a travel agency pamphlet, or some kind of mass media such as the television or the Internet. However, the media on the Internet including the accommodation booking site served as trigger for only around $8 \%$ of these visitors. Although it is likely that 
visitors used the Internet to gather information about their destination after they had booked their trip, it seems that, as ever, traditional analog sources of information still have the power to attract customers.

(7) As regards the visitors' objectives for the trip, as many as 279 visitors came for the flowers, while others came for hot springs, scenery, nature, and the cuisine/experiencing new tastes. In contrast, few visitors came to visit historical sites, monuments to literary figures, buildings, tourist facilities, art galleries, museums, or other cultural facilities, which may indicate that the natural environment in the area was sufficiently attractive for visitors.

(8) Most visitors (63\%) stayed just one night on the Izu Peninsula, while $21 \%$ returned home on the same day. In addition, $60 \%$ of visitors were from the Tokyo, Kanagawa, and Shizuoka areas. Given that they stayed one night or returned home on the same day, it appears that they consider the Izu Peninsula a handy location for a short trip.

In the Kawazu survey, the authors have not asked questions about excursion-related behavior including tourist facilities (not restricted to specific administrative districts) and accommodation sites (actual and projected business performance).

As regards tourist facilities, most respondents mentioned Kawazu (234), followed by Shimoda (65), Inatori (32), Tsurushibina (31), Atami (27), Izu Kogen (19), ropeway (12), Ito (10), Shimokamo Onsen (8), Kawazunanadaru (8), Shuzenji (8), and Tokyo (8). As this list uses the words provided by the survey res ponders, even though, for example, Inatori and Tsurushibina are in the same region, they are considered as separate responses.

Furthermore, the average number of locations visited was 2.04 overall, those with bicycles or motorbikes visited 1.89 locations, those using public transport or other transport visited 2.08 locations, day-trippers visited 1.60 locations, and those making overnight stays visited 2.11 locations.

Furthermore, $3.14 \%$ of respondents visited the west coast (Nishiizu town, Matsuzaki town). Of these respondents, $9.23 \%$ visited the area with bicycles or motorbikes, $1.75 \%$ used public transport or other transport, $3.64 \%$ were day-trippers and $3.07 \%$ made overnight stays.

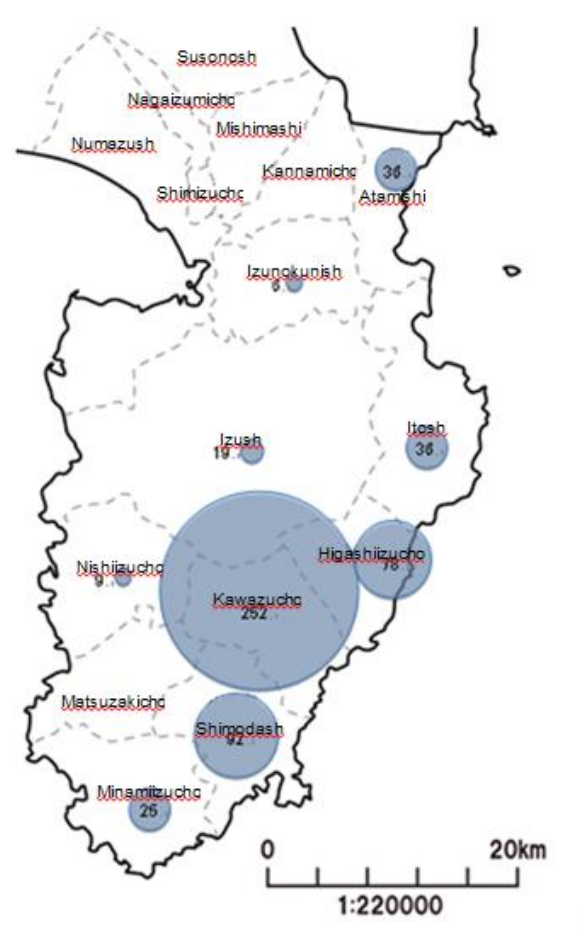

Figure 1. Destinations and number of visitors

The Results for Hypothesis Testing are as follows.

We set the following 10 Null hypotheses.

A-1) Those who are young have the image of Izu Peninsula as "sea bathing".

A-2) Those who live far away (Chugoku, Remote part of Kanto area) often use sightseeing bus. 
A-3) Those who live far away have many souvenir budget (more than 5000 Japanese Yen).

A-4) Those who are couple often visit Izu Peninsula (more than 5 times).

A-5) Those who live nearby (Shizuoka, Kanagawa, Tokyo) often visit Izu Peninsula by private automobile.

A-6) Those who felt good at the previous visit to Izu Peninsula consists mainly by repeaters.

A-7) Those who felt good at the previous visit to Kawazu Town consists mainly by repeaters.

A-8) Those who visit for the purpose of hot spring often come for more than 2 days.

A-9) Those who visit Izu Peninsula by one-day trip consist mainly by the people who live nearby (Shizuoka, Kanagawa, Tokyo).

A-10) Those who visit Izu Peninsula by the occasion of "Poster" often use JR or Izu-Kyuko train.

6 cases out of 10 are rejected and the majority of hypotheses (A-1, A-3, A-6, A-7, A-8, A-9) were insisted clearly.

\section{Conclusion}

In this paper, a questionnaire investigation is executed in order to clarify tourists' behavior, and to seek the possibility of developing regional collaboration among local government, tourism related industry and visitors. This survey of tourist behavior was carried out in February 2015, during the Kawazu Cherry Blossom Festival). The 25th Kawazu Cherry Blossom Festival was held from February 10 to March 10, 2015. It was attended by 801,330 people, which was an increase of $9 \%$ over the previous year. On the first day of the survey, $30-50 \%$ of the flowers were in bloom, and the nighttime illuminations lit up on the evening of the 21 st. According to the figures of the Kawazu town Tourist Association, there were 30,590 visitors on the 21st and 20,913 visitors on the 22nd.

During the Kawazu Cherry Blossom Festival, around 150 stores were offering food \& drink or souvenirs on the road with the row of cherry trees linked to Kawazu Station. A number of events were held during the festival, including the "Semi Gourmet" and "Izu no Odoriko Photography Event."

At around the same time (January 20 to March 31), the 18th "Hina no Tsurushikazari Festival" (Hanging Doll Festival) was held at Higashiizu town Inatori.

In order to look for policies for effective use of questionnaire surveys in tourist destinations, the present study reviewed preceding studies in the field. Moreover, an attempt was made to find possibilities for inter-regional cooperation based on the data.

In the hypothesis testing, 6 cases out of 10 null hypotheses were rejected and the majority of hypotheses (A-1, A-3, A-6, A-7, A-8, A-9) were insisted clearly. We have obtained fruitful results.

In the future, it will be necessary to continue such surveys at various locations on the Izu Peninsula using a standardized set of questionnaire items and methods, and the efficacy of the study will have to be confirmed.

\section{Acknowledgements}

This study was made possible through the extensive cooperation of the Izu DMO Council, Shizuoka Prefecture Government, Kawazu Town Office, JTB Chubu Office, and others. I would like to thank the translation and editing company ERF for creating the English language version of this study. And finally, I would like to offer my deepest thanks to everybody else who has helped me in preparing this study.

\section{References}

Doi, H. (2009). "Evaluation of policies to build tourist destinations and statistical analysis” Nippon Hyoron Sha.

Kano, M. (2011). "Characteristic analysis of Atami tourists: Reconsideration based on data add and modify" Shizuoka Economic Research, 16(2), 61-78, Shizuoka University. 


\section{APPENDIX}

\section{Questionnaire about the Tourism in Izu Peninsula}

Please select the appropriate item in each column. Please write down the details in ( ).

Q1. Address: Prefecture (

$\Rightarrow$ If the prefecture is Tokyo, Kanagawa, Shizuoka, then City (

Q2. Sex: (1)Male (2)Female
Q3. Age:
(1) 10 th
(2)20th
(3) 30 th
(4) 4 th
(5) 50 th
(6)6th
(7) $70 \sim$

Q4. Occupation: (1)Independents (2) Office worker (3)Student (4)Housewife (5)No job 6) Miscellaneous ( )

Q5. Fellow travelers:
(1) Solo trip (2)Couple
(3)Family
(4)Male's small group
(5)Female's small group
(7) Group (More than 7)
(8)Miscellaneous (

66Male and female's small group

Q6. Visiting frequency to Izu Peninsula and Kawazu Cherry Tree:

Izu Peninsula = (1)First time (2)Second times (3)Third times (4)Fourth times (5)Fifth Nine

times (6)More than ten times

Kawazu Cherry Tree = (1)First time (2)Second times (3)Third times (4)Fourth times

Fifth $\sim$ Nine times (6)More than ten times

Q7. Means of transportation to IZU Peninsula:

(1) JR, Izu-kyuko train (2)Sightseeing bus (3)Private automobile (4)Rent-a car (5)Highway bus
(6) Shuttle bus service by the hotel (7) Miscellaneous (

Q8. Means of movement in Izu Peninsula: (Plural answers allowed)
(1)Walking (2)Fixed-route bus
(6) Taxi
(7)Miscellaneous (
(3) Sightseeing bus
(4)Private automobile
(5)Rent-a car
$\rightarrow$ To whom who has selected (5): Starting point
End point (
)

Q9. Main occasion to visit to Izu Peninsula (Plural answers allowed)

$\begin{array}{llll}\text { (1) Poster (2) Brochure by tour company } & \text { (3)TV program } & \text { (4) Newspaper ad } & \text { (5)Magazine }\end{array}$

(6)Tour package for Kawazu Cherry Tree (7) Online lodging reservation site (8)Internet (9)Advice by family, acquaintance (10Felt good at the previous visit (11Miscellaneous

Q10. What is an objective to visit Izu Peninsula? (Plural answers allowed)
(1)Hot spring (2)Scenery, Nature
(3)Dish, sense of taste
(4)Flower of the season (5)Stroll around

(7) Convenience of traffic town, Eating tour (6)Budget

monument, Construction (9) Sightseeing facilities

tourism 12Park 13Miscellaneous (

(8) Historic landmark, Literature

Q11. Staying time in Izu Peninsula:
(1) One - day trip ( ) hour
(2) 2 days stay
(3) 3 days stay
(4) More than 4 days

$\Rightarrow$ If you have selected (2) (4), please answer the following question.

(1)Staying type: (1)Inn, Hotel (2)Resort house (3)Second house (4)Relative's house (5)Miscellaneous

(2)Use type of staying facilities: (1)Per night with dinner and breakfast (2)Per night with dinner (3)Per night with breakfast (4)With no meals (5)Miscellaneous ( )

Q12. Where are you going to go in Izu Peninsula? ※Place at which staying time is more than 30 minutes

$\star$ Customer type ( $\quad$ ): A: One - day trip, Depart from Kawazu Cherry Tree $\quad$ B: One - day trip, Depart from elsewhere except for Kawazu Cherry Tree C: Stay more than one night, Depart from Kawazu Cherry Tree D: Stay more than one night, Depart from elsewhere except for Kawazu 
Cherry Tree

(1)Facilities to call at

(

)$\rightarrow($

)$\rightarrow($

)$\rightarrow($

)$\rightarrow($

)

(2)Place of stay: First night 【

】 Second night 【

】

Q13. Do you want to come to Izu Peninsula again?

Q13-A: (1)Want to come again (2)Slightly want to come again (3)Slightly do not want to come again (4)Do not want to come again

$\Rightarrow$ To whom who has selected (1) and (2): What was good in Izu Peninsula?

(

To whom who has selected (3) and (4): What was not good in Izu Peninsula?

Q13-B: What season do you want to come to Izu Peninsula? (1)Spring Month ( ) (2)Summer Month ( ) (3)Autumn Month ( ) (4)Winter Month ( )

Q14. Select items in each theme concerning the attractiveness of southern part of Izu Peninsula. (Plural answers allowed)

Theme 1"sea": (1)Sea bathing (2)Activities such as diving and fishing (3)Pleasure cruiser (4)Sunset (5)Driving along the coastline (6)Open - air bath where the visitor can see the sea (7)Fresh products of the sea

Theme 2"Hot spring": (1)Feelings of the hot spring district (2Japanese-style hotel (3)Open - air bath (4)Dinner in the hotel (5)Hospitality

Theme 3"Nature": (1)Flower of the season (2)Hiking, stroll (3)Geopark (4)Experience-oriented program (5)Mount Fuji (6) Warm climate

Theme 4"Culture": (1)Temples and shrines (2)Letter bearing the shogun's scarlet seal (Voucher seals of visit) (3)Stroll around town (4)Folk craft goods (5)Local dishes

Miscellaneous : 【

【
】【

\section{】}

Q15. What do you want to be enhanced while travelling southern part of Izu Peninsula? (Plural answers allowed)

(1)Area map of southern part of Izu Peninsula (2)Total WEB site (3)Model tourism plan of southern part of Izu Peninsula (4)Tourism information for driving (5)Information for the landing-type tourism such as experience-based plan (6)Information about restaurant and shop (7)Enhancement of alternative traffic and their information (8)Miscellaneous

Q16. How about the expenditure or budget of the following items in Izu Peninsula?
(1) Lodging expense: (1) 10,000(Yen)
(2) $10,001 \sim 15,000$
(3) $15,001 \sim 20,000$
(4) $20,001 \sim 30,000$ (5) $30,001 \sim$
(2) Food and drink expense: (1) 1,000
(2) $1,001 \sim 2,000$
(3) $2,001 \sim 3,000$
(4) $3,001 \sim 5,000$ $5,001 \sim$
(3) Souvenir, Shopping: (1) 1,000
(2) $1,001 \sim 2,000$
(3) $2,001 \sim 3,000$
(4) $3,001 \sim 5,000 \quad$ (5) $5,001 \sim$
(4) Miscellaneous: (1) 1,000 (2)1,001 2,000
(3) $2,001 \sim 3,000$
(4) $3,001 \sim 5,000 \quad$ (5) $5,001 \sim$

\section{Copyrights}

Copyright for this article is retained by the author(s), with first publication rights granted to the journal.

This is an open-access article distributed under the terms and conditions of the Creative Commons Attribution license (http://creativecommons.org/licenses/by/4.0/). 